\title{
Ascocotyle (Phagicola) rara sp. n. (Digenea, Heterophyidae) from Ixobrychus exilis (Aves, Ardeidae) in Brazil
}

\author{
Vanessa Santos de Arruda ${ }^{1}$ \\ Luís C. Muniz-Pereira ${ }^{1,2}$ \\ Roberto Magalhães Pinto ${ }^{1,3}$
}

\begin{abstract}
Ascocotyle (Phagicola) rara sp. $\mathbf{n}$. is described from the intestine of Ixobryctus exilis (Gmelin, 1789), a Brazilian bittern. The new species is compared with Ascocotyle (Phagicola) angeloi Travassos, 1928 and Ascocotyle (Phagicola) mollie ni sicola (Sogandares-Bernal \& Bridgman, 1960); the main distinguishing characters are related to the aspect of the gonotyl that is not perforated in $A$. (P.) rara sp. n. when compared to $A$. (P.) mollienisicola and the absence of the crown of spines at the anteriorend in the new species compared with $A$. (P.) angeloi. This is an important finding, since human infections by Phagicola spp. have been previously reported in Brazil.

KEY WORDS. Digenea, Ascocotyle (Phagicola) rarasp. n., Ixobrychus exilis, birds, Brazil
\end{abstract}

Digeneans of the family Heterophyidae are parasites of mammals and aquatic birds, mainly ardeids. They are distributed worldwide and have a life cycle involving mollusks and fishes. The first Brazilian species from the complex Ascocotyle-Phagicola, was described by TRAvASSOS (1916), as Ascocotyle (Phagicola) angrense. It was found in Butorides striatus (Linnaeus, 1758), B. virescens (Linnaeus, 1758) and Ixobrychus exilis (Gmelin, 1789) in Angra dos Reis county, State of Rio de Janeiro. Later, TRAvASSOS (1928) described Ascocotyle (Ascocotyle) felippei from Ixobıychus exilis and Florida caerulea (Linnaeus, 1758) and Ascocotyle (Phagicola) angeloi from Ixobrychus exilis, both from Rio de Janeiro, State.

\section{MATERIALS AND METHODS}

The two digenean specimens, on which the present description is based, were collected from Ixobrychus exilis in 1921 and capture of the hosts occurred in mudflat areas (Manguinhos) of Rio de Janeiro, Rio de Janeiro State, Brazil. Measurements are in micrometers unless otherwise indicated. The figures were made with the aid of a drawing tube connected to an Olympus CBA brightfield microscope. The holotype and the paratype weredeposited in the Coleção Helmintológica do Instituto Oswaldo Cruz (CHIOC), Rio de Janeiro, Rio de Janeiro State, Brazil.

1) Laboratório de Helmintos Parasitos de Vertebrados, Departamento de Helmintoiogia, Instituto Oswaldo Cruz. Avenida Brasil 4365, 21045-900 Rio de Janeiro, Rio de Janeiro, Brasil.

2) Corresponding author. E-mail: Imuniz @ioc.fiocruz.br

3) Research Fellow CNPq. 


\section{RESULTS \\ Ascocotyle (Phagicola) rara sp. $\mathbf{n}$.}

Figs 1-3

Description. Body elongated 630-802 long, greatest width 201-216 at the ovary level. Tegument partially covered with thin spines, to the acetabular level. Cephalic crown of spines absent. Oral sucker subterminal 36-46 in diameter; oral appendage 126-129 long. Prepharynx 205-226 long; pharynx 39-43 long, 36 wide. Esophagus 108 long. Intestinal ceca extending posterior to vitellaria. Acetabulum the posterior half of body, 54 long, 57 wide. Testes at posterior end, parallel, oval; left testis 46-54 long, 75 wide, right testis 43-54 long, 72-75 wide. Seminal vesicle between acetabulum and ovary, bipartite, inflated. Cirrus pouch absent. Ovary subspherical, submedian, pretesticular, 50-54 long, 61-72 wide. Uterus conf ined between acetabulum and testicular area; uterine seminal receptacle median, pretesticular, filled with sperm. Vitellaria with seven follicles on each side, confined to ovarian-testicular zone, 118-126 long in the right side, 115 long in the left. Genital sac pre-acetabular, postbifurcal, 21 long, 31-50 wide, enclosing gonotyl with 16 pockets. Genital pore pre-acetabular, opening to right of genital sac. Eggs numerous, non operculated, 18 long, 10 wide.

Type host. Ixobrychus exilis (Gmelin, 1789), least-bittern, "socoí-escuro".

Site of infection. Intestine.

Type locality. Manguinhos mudf lat, Rio de Janeiro, Rio de Janeiro State, Brazil.

Specimens studied. CHIOC 2621 (Ascocotyle (Ascocotyle) felippei holotype, Ascocotyle (Phagicola) angrense vouchers), CHIOC 2622 (A. (A.) felippei, Ascocotyle (P.) angeloi vouchers), CHIOC 2625-26, 2699 (A. (A.) felippei, vouchers), CHIOC 2630 (A. (P.) angrense, A. ( $P$.) angeloi, vouchers), CHIOC 2631-35 (A. (P.) angrense, vouchers), CHIOC 2636 (A. (P.) angrense, A. (P.) angeloi, vouchers), CHIOC 2637 (A. (P.) angrense vouchers), CHIOC 2640, 2891, 34369 a-h, 34370 a-z a'-i', 34372 a-b (A. (P.) angeloi, vouchers), CHIOC 9334 (A. (P.) angrense holotype), CHIOC 34365 a-o, $34366 \mathrm{a}-\mathrm{d}, 34367 \mathrm{a}-\mathrm{j}, 34368 \mathrm{a}-\mathrm{g}(A .(P)$. angrense, vouchers).

Holotype. CHIOC no. 2632; paratype no. 2639 (whole mounts).

Etymology: the specific name derives from the Latin, meaning "reduced number", "of not common occurrence".

Remarks. According to SCHOLZ et al. (1997) the identification of the Ascocotyle species complex is difficult due to the small size and the fact that the cephalic crown of spines may be misinterpreted. BURTON (1958) considered the extension of the vitellaria as the main character in a taxonomic array. In addition Sogandares-BERNAL \& LUMSDEN (1963) and OstrowSKI DE NúÑEZ (1993) considered the cercariae characters also valuable, in a scheme of classification.

BURTON (1958), FONT et al. (1984) and SALGADO-MALDONADO \& AGUIRRE-MACEDO (1991) considered Phagicola Faust, 1920 and Ascocotyle Looss, 1899 as valid genera. SOGANDARES-BERNAL \& BRIDGMAN (1960) described a new genus 


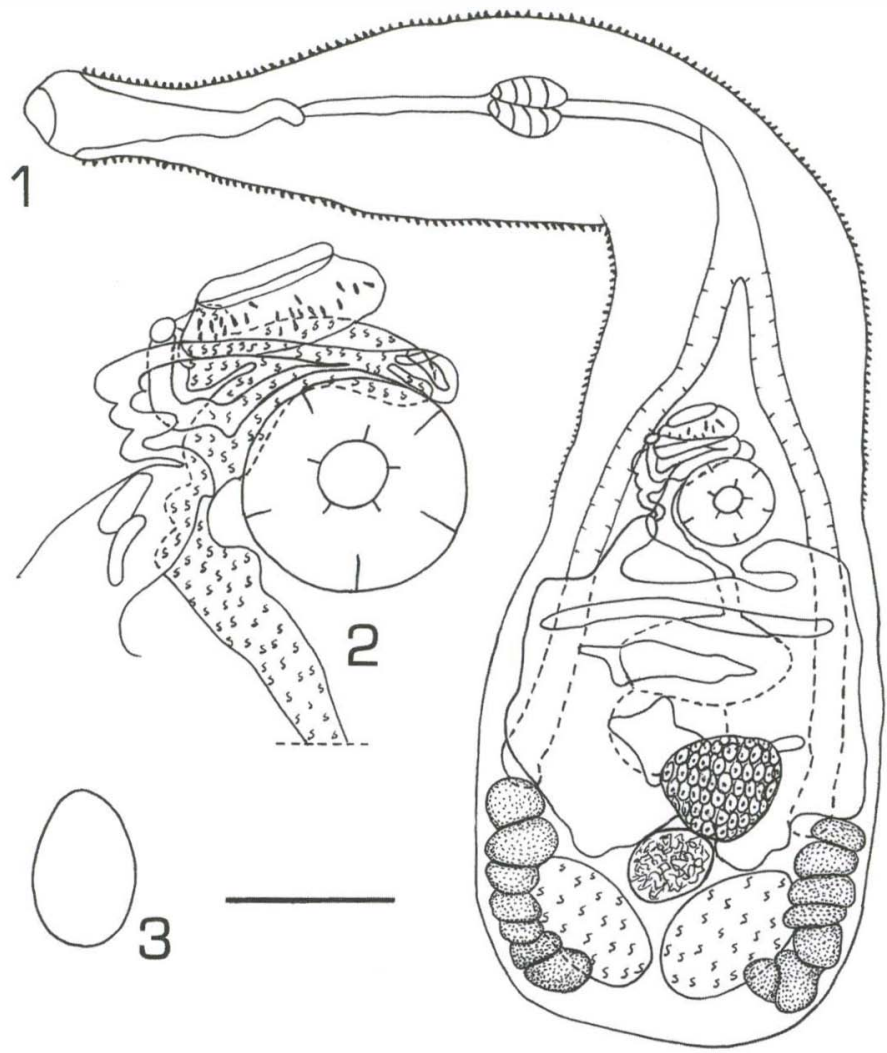

Figs 1-3. Ascocotyle (Phagicola) rara sp. n. (1) total, ventral view (Bar =0,1 mm); (2) gonotyl $(B a r=0.04 \mathrm{~mm}) ;(3)$ egg $(B a r=0.02 \mathrm{~mm})$. Bar common to figures 1-3.

and a new species, Pseudoascocotyle mollienisicola, from an experimental infection in hamsters, stating that the diagnostic character for this genus is the absence of the crown of spines and the presence of a uterine loop perforating the gonotyl. SOGANDARES-BERNAL \& LUMSDEN (1963) included Phagicola, Ascocotyle and Leighia Sogandares-Bernal \& Lumsden, 1963 as subgenera of Ascocotyle and regarded Pseudoascocotyle as a synonym of Ascocotyle, emending the diagnosis of Ascocotyle to refer to the absence of the crown of spines and suppressed the character related to the uterus perforating the gonotyl, that was considered as specific and which is corroborated in the present work. YAmAGUTI (1971) stated that Phagicola, Ascocotyle and Pseudoascocotyle are distinct genera.

The closest species, Ascocotyle (Phagicola) mollienisicola, shares with Ascocotyle ( $P$.) rara sp. $\mathbf{n}$. the absence of a crown of spines at the anterior end. The two species can be differentiated by the gonotyl, that in the latter is not perforated by the uterine loops. In $A$. ( $P$.) mollienisicola the terminal portion of the uterus enters and opens inside the genital sac and not adjacent to it as in $A$. (P.) rara $\mathbf{s p .} \mathbf{n}$. According to PEARSON (1964) the genital pore can be adjacent or surrounded by 
the gonotyl. In the gonotyl of Ascocotyle (P.) rara sp. n. (Fig. 2) we can observe pockets as reported by OSTROWSKI DE NÚN̄EZ (1998) for $A$. ( $P$.) angeloi, contrasting with $A$. ( $P$.) mollienisicola, described by the same author as presenting spines.

Ascocotyle $(P$.) angeloi possesses a double crown of spines, contrasting with Ascocotyle ( $P$.) rara sp. n., in which the crown is absent. In $A$. ( $P$.) rara sp. n., the mouth of the genital sac is absent. This differs from the observation of OSTROWSKI DE NúN̄EZ (1998) when describing A. (P.) angeloi. Ascocotyle (P.) rara sp. n. possesses the genital pore opening beside the genital sac unlike to $A$. ( $P$.) angeloi in which the genital pore opens bellow it.

In the whole mounts with the holotype and paratype specimens, respectively, of Ascocotyle (P.) rara sp. n., individuals of $A$. (P.) angeloi, $A$. (P.) angrense and $A$. (A.) fellipei were also found together. In the specimens of these other species mentioned, a well preserved collar of spines could be easily observed.

The importance of this finding is reinforced considering that Ascocotyle spp. infections can be recognized as a public health problem. Human infections due to Phagicola spp., have been reported in Brazil since 1929 by L. Travassos, who mentioned the lack of specificity of Heterophyidae worms regarding the def initive host. In their life-cycle, heterophyids cercariae infect fresh or brackish-water snails of several genera; fishes, most edible, cercariae encyst as metacercariae, to develop in the adult stage when are infective to birds and mammals, including man, that fed on parasitized fishes. CHIEFFI et al. (1992) diagnosed, by means of stool examination, nine cases of human parasitism by Phagicola sp. in B razil. Patients that fed on raw fish suffered from flatulence, diarrhea and showed slight eosinophilia.

ACKNOWLEDGEMENTS. To Dr Dante M Teixeira, head of the Ornithological Section, Museu Nacional do Rio de Janeiro (UFRJ) and to Prof. Jorge Bruno Nacinovic, Ornithological Section Museu Nacional do Rio de Janeiro (UFRJ), for reviewing the host nomenclature and discussing host taxonomic status; to Prof. Dely Noronha, FIOCRUZ Dept. of Helminthology (CHIOC), for providing the deposited helminth specimens.

\section{REFERENCES}

BURTON, P.R. 1958. A review of the taxonomy of the trematode generaAscocotyle (Looss) and Phagicola (Faust) of the family Heterophyidae. Proc. Helm. Soc. Wash. 25: 117-122,

ChiefFi, P.P.; C.O.M. Gorla; D.M.A.G.V. Torres; R.M.D.S. Dias; A.C.S. Mangini; A.V. Monteiro \& E. Woiciechovshi. 1992. Human infection by Phagicola sp. (Trematoda, Heterophyidae) in the municipality of Registro, São Paulo State, Brazil. Jour. Trop. Med. Hyg. 95: 346-348.

Font, W.F.; R.M. Overstreet \& R.W. Heard. 1984. Taxonomy and biology of Phagicola nana (Digenea: Heterophyidae). Trans. Amer. Microsc. Soc. 103: 408-422.

OSTROWSKI DE NÚNEEZ, M. 1993. Life-history studies of heterophyid trematodes in the neotropical region: Ascocotyle (Phagicola) diminuta (Stunkard \& Haviland, 1924) and A. (P.) angrense Travassos, 1916. Syst. Parasitol. 24: 191-199.

- 1998. Life cycle of Ascocotyle (Phagicola) angeloi (Digenea: Heterophyidae) in the neotropical region. Folia Parasitol. 45: 199-204.

Pearson, J.C. 1964. A revision of the subfamily Haplorchinae Looss, 1899(Trematoda: Heterophyidae). Parasitology 54: 601-676. 
Salgado-Maldonado, G. \& L. Aguirre-Macedo. 1991. Metacercarias parásitas de Cichlasoma urophthalmus (Cichilidae) Pelaezia loossi n. comb. y Phagicola angrense com descripción de adultos recuperados experimentalmente. Anales Inst. Biol. Univ. Nac. Auton. Mexico 62: 391-407.

Scholz, T.; J. Vargas-Vázquez; L. Aguirre-Macedo \& V.M. Vidal-Martínez. 1997. Species of Ascocotyle Looss, 1899 (Digenea: Heterophyidae) of the Yucatan Peninsula, Mexico, and notes on their life-cycles. Syst. Parasitol. 36: 161-181.

Sogandares-Bernal, F. \& J.F. Bridgman. 1960. Three Ascocotyle complex trematodes (Heterophyidae) encysted in fishes from Louisiana, including the description of a new genus. Tulane Stud. Zool. 8: 31-39.

Sogandares-Bernal, F. \& R.D. Lumsden. 1963. The generic status of the heterophyid trematodes of the Ascocotyle complex, including notes on the systematics and biology of Ascocotyle angrense Travassos, 1916. Jour. Parasitol. 49: 264-274.

Travassos, L. 1916. Informações sobre a fauna helmintolójica Sul-fluminense. Brazil Médico 30 (1): $1-2$.

1928. Deux novelles espéces du genre Ascocotyle Looss, 1899. C.R. Soc. Biol. Paris 100: 939-940.

1929. Contribuição ao conhecimento dos Heterophyidae. Rio de Janeiro. Thesis Escola Superior de Agricultura e Medicina Veterinária, $31 \mathrm{p}$.

Yamaguti, S. 1971. Synopsis of Digenetic Trematodes of Vertebrates. Keigaku Publ. Co., Tokyo, Vol. 1, 1074p.

Recebido em 29.VI.2001; a ceito em 14.II.2002. 